\title{
Analysis of the Influence of Regional Revenue Factors on Regional Inequality in Sumatra Island and Papua Island
}

\author{
Dr. Mona Adriana S, SE., Msi ${ }^{1}$, Agustina Suparyati, SE., ME ${ }^{2}$ \\ \{mona.as@trisakti.ac.id ${ }^{1}$ \} \\ Trisakti University, Indonesia
}

\begin{abstract}
The purpose of this study is to analyze the factors that influence inequality between provinces in Sumatra in terms of regional revenues, in this case the influence of Regional Original Revenue (PAD), General Allocation Funds (DAU) and Special Allocation Funds to the inequality that occurs between provinces in Sumatra from 2010 - 2018. The analytical method used in measuring inequality is the Willamson Index, OLS regression and the research design used is correlation research, with panel data. The results showed that for the island of Sumatra, the PAD and DAK variables were proven to affect regional inequality, while the DAK variable did not affect inter-provincial inequality. For Papua there is only one variable that affects regional inequality, namely the DAU variable, for PAD and DAK variables have no influence on regional inequality in Papua. For the development of future research, it is better to be able to analyze more deeply and especially in Papua to compare the GRDP data between GRDP without oil and with oil.
\end{abstract}

Keywords: Inequality; Williamson; Panel Data

\section{Introduction}

Inequality between regions is a problem faced by every country starting from sub-districts, districts/cities and provinces and even between islands in Indonesia. This gap is inseparable from the diversity of natural resource potential, geographical location, quality of human resources between regions. On the one hand, this diversity can be an advantage, but unfortunately on the other hand, it has the potential to increase the inequality that occurs. The Williamson index is an index used in analyzing regional inequality. The difference between this method and the Gini Ratio which is often used to calculate income distribution is the Williamson Index needed income per capita. This is because what is being compared is development among regions, not the level of income distribution. Neo Classics has the opinion causes by regional inequality are due to differences in resources, labor and technology in each region, where this results in the ability of a region to encourage the development process also to be different from one region to another.

The implementation of regional autonomy which focuses on the Regency and City Regions begins with the transfer of a number of authorities (affairs) from the central 
government to the relevant regional governments. The delegation of various authorities in the context of decentralization must of course be accompanied by transfer of financing. The expansion of new provinces since the 2000s in Sumatra and decentralization are also considered as one of the factors driving inequality to widen. To prevent it from getting wider, government policies are needed in managing revenues that come from the potential of each region. For Sumatra, inequality in the Sumatra region has been taking place in various forms, aspects and the inequality between provinces in Sumatra is caused by various obstacles, both in terms of investment, as well as the unequal potential of natural resources owned by each province.

For the provinces on the island of Sumatra, there are several provinces that have quite high inequality, such as South Sumatra, Bengkulu and Lampung. Especially for the province of Lampung since 3014 from the GRDP data obtained, the province has experienced a very high increase and decreased the value of the inequality index. Inequality of development between regions is very dependent on macro conditions that occur in each region where investment and economic stability are factors that determine the success of development that occurs in each region. Investment allocation is one of the causes that determine the level of economic development of a country or region. The pattern of investment distribution in the case of Indonesia is concentrated, especially on the island of Java, which has an impact on development inequality between one region and another. The centralization of investment in Java or the delay in the development of regional investment is caused by many factors, one of which is bureaucratic policies that are centered on limited infrastructure and human resources outside Java [1]. Meanwhile, in other regions, namely Papua, it can be seen from the regional inequality data which by looking at the Williamson index from year to year it looks very large, especially in the West Papua area with very high numbers at the beginning of the year. The strategy taken by the government is to realize a more balanced development through decentralization of government and followed by direct cooperation between the central government and the regions [2].

Several causes inequality include: (i) the allocation of sources of local government revenue that leads more to routine expenditures (wages or salaries) than to investment for infrastructure development or capital in the regions, (ii) Lack of institutional capacity (institutions) in the regions. local governments, (iii) Lack of sufficient incentives from the central government to local governments and (iv) lack of redistribution of national (central) transfers. Bonet's research also has the same conclusion as the research conducted by Woller and Phillips (1998). But despite the success of this system, fiscal decentralization also has the potential to increase regional income disparities, if not managed properly (Prud'homme, 1995; Lessmann, 2006; Shah, 2006). This concern arises because in a decentralized system, local governments have the authority to manage their own budgets, which if not supported by good planning skills will result in sub-optimal results.

The source of regional revenue that seems to play a very important role in increasing development is part of the balance, namely the General Allocation Fund, which can be seen from the data in various provinces that the DAU has a fairly large percentage contribution in the formation of the amount of regional revenue. Unfortunately, the different contributions between regions on the one hand have an impact on regional inequality between regions that are already more developed, such as the island of Java and the island of Sumatra compared to the eastern region. This is the background of the author to analyze "How is the influence of regional revenue factors on the island of Sumatra and Papua?" The purpose of the study is to analyze and examine the effect of local revenue, general and special allocation funds on inequality in Sumatra and Papua islands 


\section{Literature Review}

Economic disparities between regions are a common problem in economic development activities in a country where the tendency of development policies designed to increase economic growth can actually worsen the condition of economic disparities between regions. Economic disparities between regions are often a serious problem because some regions can achieve fast economic growth, while other regions experience slow growth. The factors that cause development inequality between regions are: (1) Differences in the content of natural resources, (2) Differences in geographical conditions, (3) Lack of smooth mobility of goods and services, (4) Concentration of regional economic activities, (5) Allocation of development funds between regions This problem can trigger population migration from underdeveloped areas to developed areas which will have an impact on the emergence of socio-economic problems in developed areas.

\subsection{The causes of inequality in development between regions}

The diversity of a region tends to cause inequality between regions and between economic sectors of a region. This describes that the inequality amongs regions is a logical consequence of development and is a stage of change in development itself. Excessive differences in the level of economic progress between regions can cause backwash effects and will dominate the beneficial effects (spread effects) on regional growth according to Myrdal. Some of the factors that cause development inequality between regions are:

\subsubsection{Differences in the content of natural resources}

Very large differences in the content of natural resources in each region can result in inequality between regions. The content of natural resources such as oil, natural gas, or land fertility certainly affects the development process in each region. There are regions that have oil and gas. natural gas is quite large, while other areas do not have it. . Likewise, the level of land fertility is also very varied so that it affects efforts to increase agricultural development in each region.

\subsubsection{Differences in Demographic Conditions}

Another factor is if there are large differences in demographic conditions between regions. Demographic conditions include the growth rate and population structure, education and health levels, employment conditions and the behavior of the people of the area.

This difference will be affected by regional inequality because it affects labor productivity in the area where areas with good demographic conditions will have high work productivity

\subsubsection{Lack of smooth mobility of goods and services}

The unequal distribution of goods and services between regions results in the emergence of development inequality from one region to another either government sponsored (transmigration) or spontaneous migration. If the mobility of goods falters, there will be excess production in an area that cannot be sold to other regions in need and will cause excess labor in an area that cannot be utilized by other regions and result in high inequality between regions. The mobility of goods and services refers to the provision of facilities and 
infrastructure as well as facilities within an area, such as: roads, bridges, means of transportation both land, sea and air and others.

\subsubsection{Differences in the Concentration of Regional Economic Activities}

The difference in the concentration of economic activity between regions which is quite high will stimulate an increase in development inequality between regions because the regional development process will be faster in regions with a higher concentration of economic activity. Likewise, if the concentration of economic activity in an area is relatively low, it will also encourage unemployment and low levels of income for the local community.

Some of the factors that cause economic activity to be concentrated in one area are 1 . the presence of areas rich in natural resources such as oil and gas and coal, 2. uneven land, sea and air transportation facilities 3. uneven demographic conditions in all regions.

\subsection{Inter-Regional Development Fund Allocation}

The local government system determines how the allocation of investment is, if the local government system used is centralized, then the allocation of government funds will lead to the central government, so that inequality between regions tends to be high. In contrast, if the government system is decentralized, more government funds will be allocated to the regions so that the development gap between regions will tend to be lower. The local government system determines how the allocation of investment is, if the local government system used is centralized, then the allocation of government funds will lead to the central government, so that inequality between regions tends to be high. In contrast, if the government system is decentralized, more government funds will be allocated to the regions so that the development gap between regions will tend to be lower.

\subsection{Balancing Fun}

Balancing funds are funds sourced from the State Revenue and Expenditure Budget (APBN) and allocated to regions for regional needs in the context of implementing decentralization. The purpose of the balancing fund is to ensure that the availability of regional funds is balanced between the Government, the Central Government and between Regional Governments. The role of the Regional Government must emphasize their respective roles and functions, especially the legislative function, supervisory function, and budget function in the administration of local government.

\section{Types of balancing funds}

a) Regional Share/Tax Revenue Sharing/Profit Sharing Fund (DBH)

Revenue-sharing funds are funds sourced from APBN revenues that are allocated to regions based on percentage figures to meet the needs of regional funds in the context of implementing decentralization, such as tax revenue sharing funds (DBHP) and non-tax revenue sharing funds (DBHBP). The profit sharing fund is divided based on a certain percentage for the central government from the exploitation of natural resources such as oil and gas, mining and forestry which is divided in various portions between the central, provincial, district and city governments. 
b) General allocation fund (DAU)

General allocation funds are funds sourced from APBN revenues which are allocated for equitable distribution of financial capacity among regions and are used as a source of funds to meet regional needs. The allocation of these funds is to help finance special activities in certain regions which are regional affairs and in accordance with national priorities, such as financing the needs of basic public service facilities and infrastructure that have not yet reached certain standards or to encourage the acceleration of regional development.

General Allocation Funds are block grants given to all districts/cities aimed at filling the gap between their fiscal capacity and needs, which are distributed using a formula based on certain principles which generally indicate that poor and underdeveloped regions should receive more than rich regions. In other words, the important purpose of the DAU allocation is to equalize the ability to provide public services between local governments.

\section{c) Special Allocation Fund (DAK)}

Based on Law no. 33 of 2004, Special Allocation Funds are funds sourced from APBN revenues allocated to certain regions with the aim of financing special activities which are regional affairs and in accordance with national priorities. DAK is intended for special programs owned by local governments. The allocation is not used to build facilities and infrastructure for remote areas or those who do not have access, but it is also used for physical facilities and infrastructure in the region with the aim of overcoming the impact of environmental damage.

\subsection{Research Hypothesis}

The research conducted by the researcher is integrated in nature, where the influence of various variables related to the progress of a region is analyzed in an integrated manner.

Based on the description of the theoretical framework and taking into account the path diagram that is described based on the theory, this study formulates a hypothesis in order to determine the factors that affect the condition of an area in all regencies/cities in Indonesia as follows:

H1 : Regional Original Revenue has a positive effect on Inequality between Regions

$\mathrm{H} 2$ : The General Allocation Fund has a positive effect on Inequality between Regions

H3 : The Special Allocation Fund has a negative effect on Inequality between Regions

\section{Research Methodology}

The data used in this study is pooling data, which is a combination of time series and cross section data from 2000 to 2018 for Sumatra and data obtained from the Central Statistics Agency (BPS) and other literature. The data in this study were tested using statistical tests using Eviews 9.0 software. To determine the number of inequality using the Williamson index, with the following formula:

$$
I W=\frac{\sqrt{\sum\left(Y_{i}-Y\right)^{2} \frac{f_{i}}{n}}}{Y}, 0<I W<1
$$




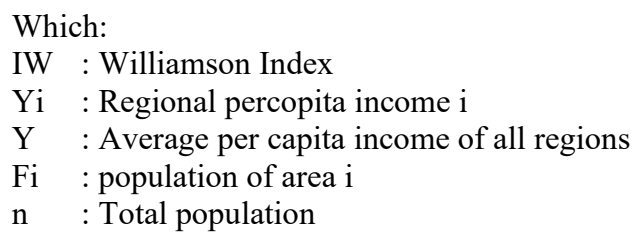

The coefficient of the Williamson Index is $0<$ IW $<1$. If the value leads to zero, the inequality becomes smaller and more evenly distributed.

The model design that will be proposed is a linear regression model with nine independent variables and one dependent variable, namely regional inequality. The specifications of the model are econometrically as follows:

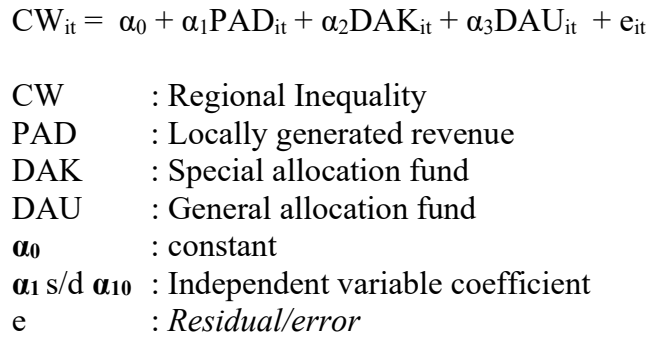

\section{Result and Discussion}

Sumatra Island consists of Aceh, North Sumatra, West Sumatra, Riau, Jambi, South Sumatra, Bengkulu, Lampung, Bangka Belitung Islands and Kep. Riau is an island rich in agricultural products. Of the five provinces that are rich in natural products in Indonesia, three are located on the island of Sumatra, namely the provinces of Aceh, Riau and South Sumatra. Sumatra's main products are oil palm; tobacco; crude oil ; lead; bauxite; coal and natural gas.

The main problem faced in Sumatra is the condition of natural resources that are potentially uneven in all regions where some areas that have potential natural resources are the biggest contributors to economic conditions on the island of Sumatra, in this case the largest natural resources are located in Riau province, both oil and gas. and non-oil and gas which is very famous for its oil wealth and there are many oil refineries that produce crude oil every day. In terms of non-oil and gas, Riau has large non-oil exports and is a leading sector, namely crude palm oil (CPO) whose export value is increasing from year to year.

When viewed from the contribution of PRDB, it can be seen that the provinces that provide the largest contribution to the formation of GRDP are Riau, West Sumatra and South Sumatra. originating from the manufacturing sector, with $37 \%$ of the construction sector being the second largest contributor (19\%) and followed by the quarrying and mining sector (14\%). [3], while the province of West Sumatra is the province that provides the smallest contribution to PRDB. And it can be seen that there are quite large differences between several regions in Sumatra itself, such as the GRDP between North Sumatra and South Sumatra compared to the GRDP of West Sumatra.

Meanwhile, from the allocation of the use of DAU and DAK, it can be seen that the role of DAU and DAK in the formation of regional revenues in Sumatra is quite large, in fact there 
are some areas that exceed 50\%, such as West Sumatra, Jambi and Bengkulu. It can be concluded that DAU and DAK play an important role in Sumatra.

One of the provinces that received high DAU and DAK numbers was in Bengkulu province, where the funds were used to develop the tourism sector in the South Bengkulu area and infrastructure development, in this case there were 13 areas for DAK allocation, namely education, health and family planning. , roads, drinking water, sanitation, housing and settlements, irrigation, small and medium industries, tourism, marine and fisheries, markets, agriculture and small-scale energy.

\subsection{Hypothesis Testing}

From the results of testing the variables PAD, DAU and DAK on regional inequality on the island of Sumatra, PAD and DAU proved to have a negative effect on IW, while the DAK variable had no effect on IW on the island of Sumatra and the ability of the independent variable in explaining IW was $17.64 \%$, while the rest is explained by other independent variables that are not included in the model.

Table 1. Estimated Results of Multiple Linear Regression on Sumatra Island

\begin{tabular}{lccccc}
\hline Variable & Theory & \multicolumn{2}{c}{$\begin{array}{c}\text { Model } \\
\text { Pulau Sumatera }\end{array}$} & Summary & Decission \\
\cline { 2 - 4 } & & Beta & $\begin{array}{c}\text { Pvalue } \\
\text { (One Tail)* }\end{array}$ & \\
\hline Konstanta & & 0.805413 & 0.0000 & & \\
PAD & - & -0.060099 & 0.0015 & Significant negative & $\mathrm{H}_{1 \mathrm{a}}$ accepted \\
DAU & - & -0.011233 & 0.0006 & Significant negative & $\mathrm{H}_{2 \mathrm{a}}$ accepted \\
DAK & - & 0.007761 & 0.3375 & Not Significant positive & $\mathrm{H}_{3 \mathrm{a}}$ rejected \\
\hline Goodness of Fit & & & \\
Adj R2 : 17,64\% & & \\
F Test $\rightarrow$ The prob value of F stat $0,000439<0,05$ & $\rightarrow$ accepted & \\
Description: *p value devided by two &
\end{tabular}

$\mathrm{IW}_{\mathrm{it}}=0.805413-0.060099 \mathrm{PAD}_{\mathrm{it}}-0.011233 \mathrm{DAU}_{\mathrm{it}}+0.007761 \mathrm{DAK}_{\mathrm{it}}+\mathrm{e}_{\mathrm{it}}$

For the Papua region, the variable that affects IW is PAD which has a negative effect on inequality, while the DAU and DAK variables do not affect the inequality that occurs in Papua and have a coefficient of determination of $71.3 \%$, which means that both variables are able to explain IW in Papua of $71.3 \%$.

Table 2. Estimated Results of Multiple Linear Regression for Papua Island

\begin{tabular}{lccclc}
\hline Variable & Theory & \multicolumn{2}{c}{$\begin{array}{c}\text { Model } \\
\text { Pulau Papua }\end{array}$} & Summary & Decission \\
\cline { 2 - 4 } & & Beta & $\begin{array}{c}\text { Pvalue } \\
\text { (One Tail)* }\end{array}$ & \\
\hline Contant & & 12.07689 & 0.0246 & & \\
PAD & - & -0.028323 & 0.4851 & Not Significant negative & $\mathrm{H}_{1 \mathrm{~b}}$ rejected \\
DAU & - & -5.847668 & 0.0004 & Significant negative & $\mathrm{H}_{2 \mathrm{~b}}$ accepted \\
DAK & - & 0.855802 & 0.0013 & Significant positive & $\mathrm{H}_{3 \mathrm{~b}}$ rejected \\
\hline
\end{tabular}

Goodness of Fit

Adj R2 s:71,37\%

$\mathrm{F}$ Test $\rightarrow$ The prob value of $\mathrm{F}$ stat $0,000113<0,05 \rightarrow$ lulus 
Description: *p value devided by two

$\mathrm{IW}_{\mathrm{it}}=12.07689-0.028323 \mathrm{PAD}_{\mathrm{it}}-5.847668 \mathrm{DAU}_{\mathrm{it}}+0.855802 \mathrm{DAK}_{\mathrm{it}}+\mathrm{e}_{\mathrm{it}}$

\section{Conclusions}

Variables that affect inequality on the island of Sumatra are PAD and DAU which have a negative influence on regional inequality, while DAK has no effect. For Papua Island, there is only one variable that affects regional inequality, namely the DAU variable. The PAD and DAK variables have no effect on regional inequality. Suggestions for further research are using other measures of inequality such as Theil Index which can accommodate the sources of existing income inequality for further research and should be able to analyze more deeply and especially in Papua by comparing the GRDP data between GRDP without oil and with oil.

\section{References}

[1] T. Tambunan, Indonesian Economy. Jakarta: Ghalia Indonesia, 1996.

[2] R. Vickerman, "High-speed rail and regional development: the case of intermediate stations," J. Transp. Geogr., vol. 42, hal. 157-165, 2015.

[3] Badan Pusat Statistik Republik Indonesia, Regency/City Government Financial Statistics. BPS catalog: 7203003. ISBN: 0126-4133. Jakarta: Central BPS, 2012. 